\section{Eradicating nuclear weapons}

SIR - In your apologia for nuclear proliferation (Nature 376, 371-372; 1995) you say that the "taste of the forbidden fruit cannot be forgotten", but the rest of the leading article fails to do justice to the memory of Hiroshima and Nagasaki. It is the opponents of nuclear energy and weaponry who are trying to preserve the memory of this "fruit" while the nuclear powers are doing their best to forget. You welcome the Comprehensive Test-Ban Treaty as inhibiting the development of new weapons, but this view is contradicted by France's declaration that it will stop testing only when it has perfected the capability of simulating explosions by other means. France, and presumably the other nuclear powers, will then retain the means for developing more weapons. Unless the nuclear powers make an unambiguous commitment to disarm there can be no incentive for other nations to respect the Non-Proliferation Treaty.

It is often asserted that the two bombs dropped on Japan were necessary to complete victory over fascism. But it appears that fascism won the more lasting victory by establishing mass annihilation of civilian populations as a valid strategy of war. The West has spoken many fine words about human rights, but actions speak louder than words and few actions speak louder than these two bombs. It may be that nuclear weapons bring short-term benefits for their owners (although your statement that there has been "no armed conflict of any kind in Western Europe" can only be justified if you regard Northern Ireland as part of another continent), but there is absolutely no evidence that they have made the world peaceful in the past 50 years.

There are obviously enormous difficulties in the way of complete eradication, but since we have completed the by no means insignificant task of splitting the atom, it would be irresponsible to abandon attempts to control the consequences. As you say, the dangers of nuclear war are well known. There is a real possibility that international cooperation based on this common knowledge would develop if only the nuclear powers could be persuaded to give up their weapons of mass destruction.

\section{Martin Juckes}

Goethestraße 47,

80336 München, Germany

SIR - In a leading article "Physics not guilty", you say that "Oppenheimer had earlier argued against the bombing of Japan, urging a demonstration of the power of the bomb instead". I think he took the opposite view. Oppenheimer was one of four members of the Scientific Panel (the others were Arthur Compton, Enrico Fermi and Ernest Lawrence) nominated by the Interim Committee appointed in May
1945 by Henry Stimson, the US Secretary of War. In its recommendation of 16 June 1945 , the panel concluded that "we can propose no technical demonstration likely to bring an end to the war, we see no acceptable alternative to direct military use"

You also say that "Oppenheimer's plea for openness was vindicated, a few months after Hiroshima, by the publication of the Smyth report describing in detail and plain language what fission was about". In fact, the Americans were so keen on early publication of the Smyth report that on 12 August 1945 it was released for the Sunday morning newspapers ${ }^{3}$. So rather than a few months after Hiroshima, publication took place a few days before.

Jan H. J. Oelering

Hofwijkstraat 4,

6825 AL Arnhem,

The Netherlands

2. Sherwin, M.J. A World Destroyed (Knopf, New York, 1975).

3. Groves, L. R. Now it Can be Told (Deutsch, London,

\section{Marine marinades}

SIR - The letter from Milton Freeman (Nature 376, 11; 1995) on the dispute about whale species enriching Japanese rice bowls seems to report a major scientific finding, which should have deserved frontpage coverage.

The author suggests that marination may have caused a DNA sequence to be identified as "midway between a minke and humpback". To my knowledge, this is the first report of species hybridization by marination. New prospects for genetic engineering? Is that marinade recipe patented?

\section{Berthold Heinze}

Borschkegasse 16

A-1090 Vienna,

Austria

SIR - Freeman refers to an advertisement placed by this company in the 20 April issue of Nature, as well as our reporting of the whale DNA work of Baker and Palumbi. The advertisement in question was actually an older advertisement from the 15 September 1994 issue, which was used by Nature in order to meet press deadlines. The materials for the advertisement that we intended to place were unfortunately late arriving at the Nature offices.

Thus the copy in the printed advertisement did not contain information on more recent developments in Baker and Palumbi's work. For example, last December, the US Fish \& Wildlife Service ruled that wholly synthetic DNA made with the novel PCR procedure described in Baker and Palumbi's paper is "not subject to per-
1. Nature 376, 102 (1995). mitting or other requirements of CITES or federal conservation statutes, such as the Endangered Species Act" and further recognized "the contribution of DNA synthetics in wildlife forensic investigations". The Fish \& Wildlife Service deserves special credit for this regulatory flexibility, as its rapid endorsement of this novel PCR procedure enables US scientists to use a powerful molecular technique in studying and transporting the DNA of endangered species of flora and fauna.

\section{John Hansen}

MJ Research Inc.

149 Grove Street,

Watertown ,

Massachusetts 02172, USA

Further comments on this matter will appear in later issues of Nature.

\section{Fewer notes}

SIR - In a recent book review, the comment by Emperor Joseph 1l, "Too beautiful for our ears, my dear Mozart, and vastly too many notes", was cited in connection with La Clemenza di Tito (1791) (ref. 1). Assuming it is authentic, this imperial observation actually refers to the earlier opera Die Entführung aus dem Serail (1782) (ref. 2). By the time of Tito, Mozart had achieved conciseness.

Martin F. Heyworth

Department of Internal Medicine,

University of North Dakota,

VA Medical and Regional

Office Center (111),

Fargo, North Dakota 58102, USA

1. Lock, S. Nature 375, 642-643 (1995).

2. Landon, H. C. R. (ed.) The Mozart Compendium: A Guide to Mozart's Life and Music (Schirmer, New York, 1990).

\section{Justifiable discrimination}

SIR - I was interested to see (Nature 376, $202 ;$ 1995) that the Genetics Interest Group and others wish to give the government the powers to act against those found guilty of "genetic discrimination" in employment.

The discovery at the age of eight that I was colour blind, and hence that my chosen career of train driver was closed to me, was indeed a grievious blow. Other careers (such as airline pilot) were also closed, and although I never attempted it, my guess is that admission to art school might have proved dodgy. I have to say that I believe that all these discriminations are totally justified.

Alan D. B. Malcolm

Institute of Food Research,

Earley Gate,

Whiteknights Road,

Reading RG6 2EF, UK 